\title{
Rapid Detection of Yeast in Orange Juice by Enzyme-linked Immunosorbent Assay
}

\author{
Motonobu Yoshida, ${ }^{\dagger}$ Hisao MAEdA* and Yasushi IfukU* \\ Research Institute of Food Science, Kinki University, Higashi-Osaka, Osaka 577, Japan \\ * Wakayama Agricultural Biological Institute Center, \\ Wakayama 649-61, Japan \\ Received May 16, 1991
}

\begin{abstract}
Antisera against native yeast of 6 species, Candida intermedia, C. parapsilosis, C. guilliermondii, C. lambica, Crytococcus laurentii, and Rhodotorula rubra, were prepared for use as probes in an enzyme-linked immunosorbent assay (ELISA). These antisera reacted with yeast cell surface antigens that are thought to consist of protein moieties. The cross-reactivities between the antisera and yeast of 11 species were investigated by immunofluorescent and immunoblotting methods. It was shown that ELISA using the antiserum against $C$. intermedia or $C$. parapsilosis, is a valuable means of detecting yeast in orange juice. Yeast of more than $10^{3}$ were capable of being detected by ELISA.
\end{abstract}

In the food industry, improved techniques for the rapid detection of contamination in foods should be developed to put food products on the market sooner. Until now, some techniques have been developed, such as ATP measurement, direct epifluorescent filter technique, and electrical measurement. ${ }^{1)}$ However, these techniques are applicable only in restricted fields and they have certain disadvantages. In orange juices, especially, the lower $\mathrm{pH}$ and mingled substances have an adverse effect on ATP measurement and electrical measurement. Recently, Lin and Cousin ${ }^{2)}$. reported the application of immunological methods for the detection of moulds in tomato puree. In this study, we investigated the propriety of immunological methods for the rapid detection of yeast in orange juice. This is the first study to show the application of immunological methods for the detection of contamination in fruit juice.

\section{Materials and Methods}

Yeast cultures. Candida intermedia (ATCC 14439), Candida guilliermondii (ATCC 6260), Candida lambica
(ATCC 24750), Candida parapsilosis (ATCC 10232), Candida freyschussii (ATCC 18737), Candida sake (ATCC 14478), Rhodolorula rubra (ATCC 4558), Rhodotorula minuta (IFO 0932), Rhodotorula glutinis (IFO 0415), Cryptococcus laurentii (ATCC 18803), and Cryptococcus albidus (ATCC 10666) were obtained from Institute for Fermentation, Osaka (IFO). Each yeast was grown at $24 \mathrm{C}$ in culture media ( $\mathrm{pH} 6.0$ ) containing $0.5 \%$ peptone, $0.3 \%$ yeast extract, $0.3 \%$ malt extract, and $1.0 \%$ glucose.

Preparation of antiserum. Native cells of $1 \times 10^{9}, C$. intermedia, $C$. guilliermondii, C. lambica, C. parapsilosis, $R$. rubra, or $C r$. laurentii were suspended in $1 \mathrm{ml}$ of $0.01 \mathrm{M}$ phosphate buffer containing $0.15 \mathrm{M} \mathrm{NaCl}$, pH 7.1 (PBS), mixed with the same amount of Freund's complete adjuvant (Difco Lab.) and used as antigen for the preparation of antiserum. Male rabbits were immunized by injecting antigens subcutaneously. Four injections at intervals of 1 week were given and the rabbits were bled to death 1 week after the last injection. As a control, serum was withdrawn from rabbits before the first injection.

Indirect immunofuorescence microscopy. Cells of $1 \times$ $10^{7}$ were incubated for $30 \mathrm{~min}$ on ice with several shakings in $200 \mu \mathrm{l}$ of 20 -fold diluted antiserum according to a previous paper ${ }^{3)}$ The cells were washed, suspended in $1 \mathrm{ml}$ of PBS, and added to $20 \mu \mathrm{I}$ of 50 -fold diluted fluorescein-conjugated goat anti-rabbit IgG serum (Organon Teknika N. V.-Cappel Products). The incubation was carried out on ice for $30 \mathrm{~min}$ with several shakings. The labeled cells were washed with PBS and resuspended in

$\uparrow$ To whom correspondence should be sent. 
$200 \mu \mathrm{l}$ of PBS. In the enzyme treatment, $1 \times 10^{7}$ cells were incubated with Pronase (Kaken Pharm. Co., $1 \mathrm{mg}$ in $0.1 \mathrm{ml}$ of $0.01 \mathrm{~m}$ phosphate buffer, $\mathrm{pH} 7.0$ ), glycosidase (Seikagaku Co., $1 \mathrm{mg}$ in $0.1 \mathrm{ml}$ of $0.05 \mathrm{~m}$ acetate buffer, $\mathrm{pH} 4.0$ ) or lipase (Sigma, $1 \mathrm{mg}$ in $0.1 \mathrm{ml}$ of $0.01 \mathrm{M}$ phosphate buffer, $\mathrm{pH} \mathrm{7.0)}$ at $37^{\circ} \mathrm{C}$ for $1 \mathrm{hr}$. In the treatment with more than two kinds of enzyme, cells were washed with PBS and suspended in proper buffer. Observations were made with an Olympus fluorescence microscope, and photographs were taken with Kodak high speed Ektachrome.

Polyacrylamide gel electrophoresis (PAGE) and immunobloting. Sodium dodecyl sulfate (SDS)-PAGE in $10 \%$ gels was carried out using the standard method. ${ }^{4)}$ For transfer to nitrocellulose filters (BA 85, Schleicher and Schuell), the method of Towbin et al. ${ }^{53}$ was used. For SDS-PAGE, cells were treated ten times with a ultrasonifier (Branson, step 4) for $10 \mathrm{sec}$, and incubated with tunicase (Yamatokasei, $2 \mathrm{mg}$ in $0.1 \mathrm{ml}$ of $0.01 \mathrm{M}$ phosphate buffer, $\mathrm{pH} 7.0$ ) at $35^{\circ} \mathrm{C}$ for $2 \mathrm{hr}$ to promote cell lysis. After centrifugation, the particulate fractions were suspended in 2-fold concentrated sample buffer for SDS-PAGE and incubated for $10 \mathrm{~min}$ in boiled water. Enzyme treatment was carried out under the same conditions as in indirect immunofluorescent microscopy after treatment with tunicase.

Procedure by enzyme-immunosorbent assay (ELISA). Ten to $1 \times 10^{8}$ of yeast in $100 \mu$ lof orange juice or PBS was added to the wells of polyvinylchloride microtiter plates (Dynatech). They were incubated with vigorous shakings at room temperature for $2 \mathrm{hr}$, and then washed once with PBS. To prevent non-specific binding of antibodies to the wells, a blocking solution ( $1 \%$ gelatin, $1 \% \mathrm{BSA}$, and $0.1 \% \mathrm{NaN}_{3}$ in PBS) was added to the wells, incubated with vigorous shakings at room temperature for $2 \mathrm{hr}$, and then washed once with PBS. One hundred $\mu \mathrm{l}$ of 100-fold diluted antiserum was added to each well and incubated at room temperature for $2 \mathrm{hr}$. After washing four times, plates were incubated at room temperature for $2 \mathrm{hr}$ with $100 \mu \mathrm{l}$ of 500 -diluted horseradish peroxidaseconjugated anti-rabbit IgG serum $(0.5 \mathrm{mg} / \mathrm{ml})$ per one well and washed four times with PBS. One hundred $\mu 1$ of $0.1 \mathrm{mg}$ 3,3',5,5'-tetramethylbenzidine per $\mathrm{ml}$ of $0.1 \mathrm{M}$ acetate buffer (pH 6.0), was added to each well and the plates were incubated for $20 \mathrm{~min}$ at room temperature. The optical density of each well was measured at $655 \mathrm{~nm}$ with an ELISA reader (Biorad, model 355). In Figs. 5 and 6, each experiment was carried out in triplicate. Experimental values were obtained by the subtraction of control values from the experiment without first antibodies.

Orange juice samples. Orange juice samples (pH 3.3, $11^{\circ}$ Brix) without preservative were obtained directly from the Wakayama processing factory and were kept at $4^{\circ} \mathrm{C}$ for several weeks to months.

\section{Results and Discussion}

(1) Characterization of antiserum against yeast by indirect immunofluorescent methods We selected yeast as the object of contamination in orange juice, following the data reported by Kobatake et al. ${ }^{6)}$ who indicated that yeast predominated in fruit juice and that the species of yeast were mainly Candida, Cryptococcus, and Rhodotorula. The antisera against native yeasts were prepared and characterized to clarify the propriety of their usage as probes for an enzyme-linked immunosorbent assay (ELISA). If these antisera were to be used as probes to detect native yeast in orange juice

Table I. Detection of Candida, Cryptococcus, And Rhodotorula Cell Surface Antigens by Fluorescence Microscopy

\begin{tabular}{|c|c|c|c|c|c|c|c|}
\hline \multirow{2}{*}{ Strain } & \multicolumn{7}{|c|}{ Antiserum } \\
\hline & Candida $i$ & Candida $p$ & Candida g & Candidal & Cryptococcus $l$ & Rhodotorula $r$ & Control \\
\hline Candida $i$ & +++ & ++ & +++ & - & - & - & - \\
\hline Candida $p$ & +++ & +++ & ++ & - & + & +++ & - \\
\hline Candida $g$ & ++ & ++ & +++ & - & - & - & - \\
\hline Candida $l$ & ++ & +++ & + & +++ & ++ & ++ & -- \\
\hline Candida $f$ & + & + & - & + & + & + & - \\
\hline Candidas & + & ++ & $+t+$ & - & - & - & - \\
\hline Cryptococcus $l$ & + & ++ & - & ++ & +++ & - & - \\
\hline Cryptococcus a & - & + & + & + & + & - & - \\
\hline Rhodotorula $r$ & + & - & + & + & ++ & +++ & - \\
\hline Rhodotorula $m$ & + & - & - & - & - & + & - \\
\hline Rhodotorulag & + & + & - & - & + & +++ & - \\
\hline
\end{tabular}

Fluorescence intensity: +++ , strong; ++ , moderate; + , weak; - , negative. 

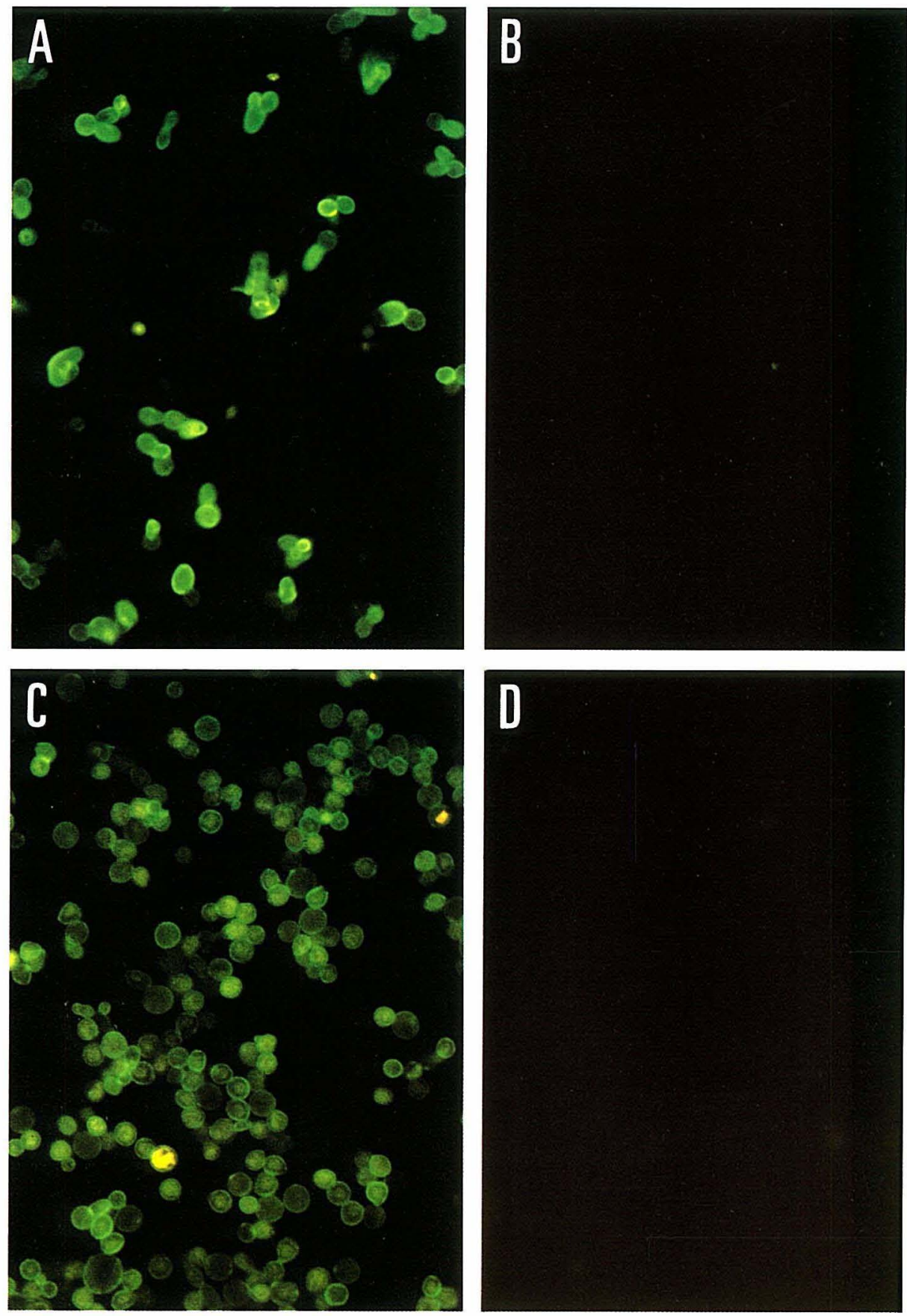

Fig. 1. Immunofluorescent Photographs of Native C. intermedia (A) and C. guilliermondii (C) Treated with Homologous Antiserum.

Instead of each antiserum, preimmune serum was used as control (B, D). 
and to discriminate between living and dead cells, it is essential that they react with the cell surface antigen of native yeast. The immunofluorescence was uniformly emitted from the cell surface using either antiserum against $C$. intermedia or C. guilliermondii (Figs. $1 \mathrm{~A}$ and B). Cross-reactivities among yeasts of 11 species were investigated using antisera against yeasts of 6 species (Table I). For the detection of contamination in food products, it is important that antisera have cross-reactivities with many other species. The antiserum against $C$. intermedia reacted with yeasts of 10 among 11 species. This shows that this antiserum could be used as a valuable probe. Though Lin and Cousin $^{2)}$ showed cross-reactivity among their antisera against mould, the antiserum against Geotrichum candidum or Rhizopus stolonifer had a reactivity with only a few species of mould. The antiserum against $C$. intermedia did not react with only $C r$. albidus among 11 species, while antisera against $C$. parapsilosis, C. guilliermondii, or C. lambica reacted with $C r$. albidus. Therefore, if the antiserum against $C$. intermedia could be mixed with one of the three kinds of antisera which reacted with $\mathrm{Cr}$. albidus, the mixed antisera could be a valuable probe that would react with all species of yeasts examined. The result from $C$. lambica was different from those from the other Candida species. From the point of view of taxonomic study, the results suggest that $C$. lambica might be located apart from the other Candida species. Though Tsuchiya et $a l^{7)}$ indicated a new classification of yeast by an immunological approach, they did not refer to the difference between $C$. lambica and the other Candida species. To investigate the properties of the antigenicities recognized by these antisera, yeast was treated with glycosidase, lipase, and/or Pronase under the conditions described in Materials and Methods. The antigenicity was remarkably influenced by Pronase treatment (Table II). This suggests that cell surface antigens consists of protein moieties. The results concerning antigenicity are of much interest in immunological studies, since it is known that the antiserum against carbohydrate moieties has cross-reactivity with lots of different substances ${ }^{8,9)}$ and that the yeast
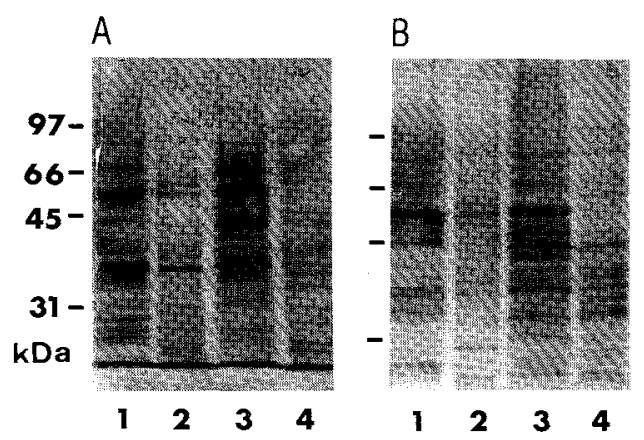

Fig. 2. Cross-reactivities between four Candida Species and the Antiserum against $C$. parapsilosis (A) or $C$. intermedia (B).

After pretreatment of samples, immunoblots were carricd out as described in Materials and Methods: (1) $C$. parapsilosis, (2) C. lambica, (3) C. intermedia, (4) C. guilliermondii.

Table II. Antigenicity of Candida Cell Surface Treated with Various Enzymes

\begin{tabular}{lccc}
\multicolumn{1}{c}{ Treatment } & \multicolumn{3}{c}{ Homologous antiserum } \\
& C. intermedia & C. parapsilosis & C. guilliermondii \\
No treatment & +++ & +++ & +++ \\
Lipase-Pronase & ++ & ++ & ++ \\
Glycosidase-Pronase & ++ & ++ & ++ \\
Lipase-Glycosidase-Pronase & + & ++ & ++ \\
Glycosidase-Lipase-Pronase & + & +++ & ++ \\
Pronase & ++++ & ++++ & +++ \\
Lipase Glycosidase & +++ & + & ++
\end{tabular}

Fluorescence intensity: ++++ , very strong; +++ , strong; ++ , moderate; + , weak. 
cell wall mainly consists of mannan and glucan. ${ }^{10,11)}$

(2) Characterization of antiserum against yeast by immunoblotting tests

Four antisera against $C$. parapsilosis, $C$. intermedia, $C$. guilliermondil, or C. lambica cross-reacted with particulate fractions of the

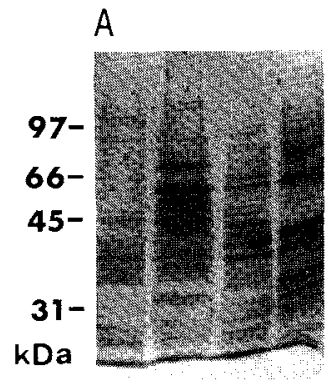

$\begin{array}{llll}1 & 2 & 3 & 4\end{array}$

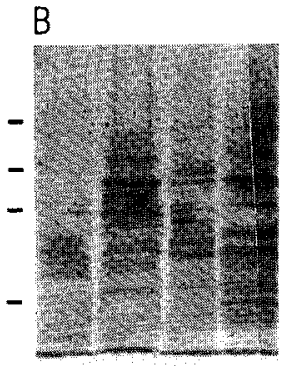

$\begin{array}{llll}1 & 2 & 3 & 4\end{array}$
Fig. 3. Cross-reactivities between four Candida Species and the Antiserum against $C$. guilliermondii $(\mathrm{A})$ or $C$. lambica (B).

After pretreatment of samples, immunoblots were carried out as described in Materials and Methods: (1) $C$. guilliermondii, (2) C. intermedia, (3) C. lambica, (4) C. parapsilosis.

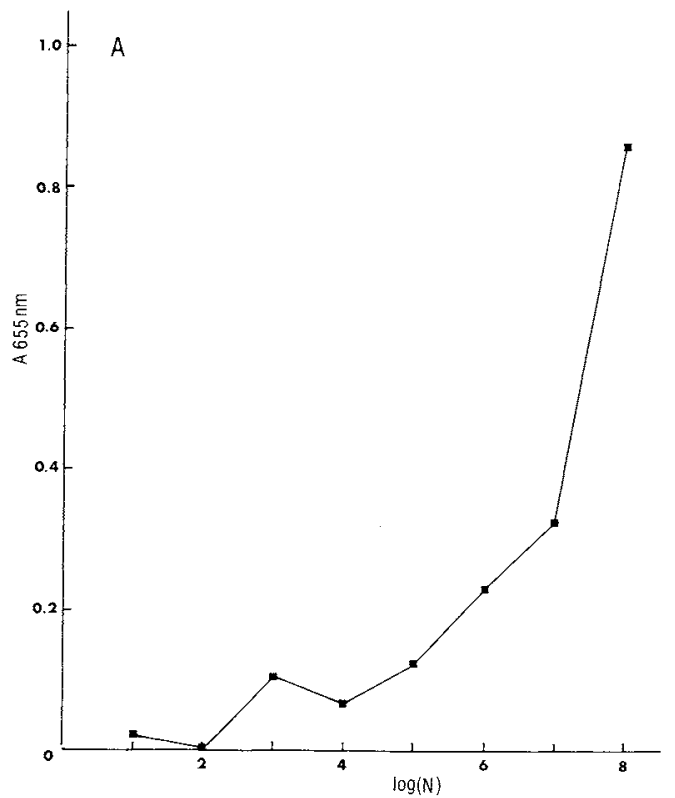

same four species (Figs. 2 and 3). The results of cross-reactivity by antisera against three species, $C$. guilliermondii, $C$. intermedia, and $C$. parapsilosis, coincided with those of indirect immunoflorescence. Though the antiserum against $C$. lambica showed cross-reactivity among four Candida species, the result is not in accord with that of indirect immunofluorescence. To explain this inconsistency, it is
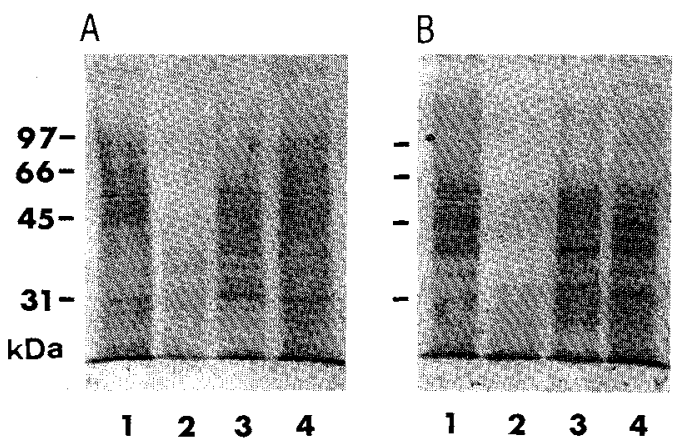

Fig. 4. Effects of Various Enzymes on the Antigenicity of C. parapsilosis (A) and C. intermedia (B).

Each yeast was treated with various enzymes: (1) glycosidase, (2) Pronase, (3) lipase, (4) no treatment. Immunoblots were carried out by using homologous antiserum as described in Materials and Methods.

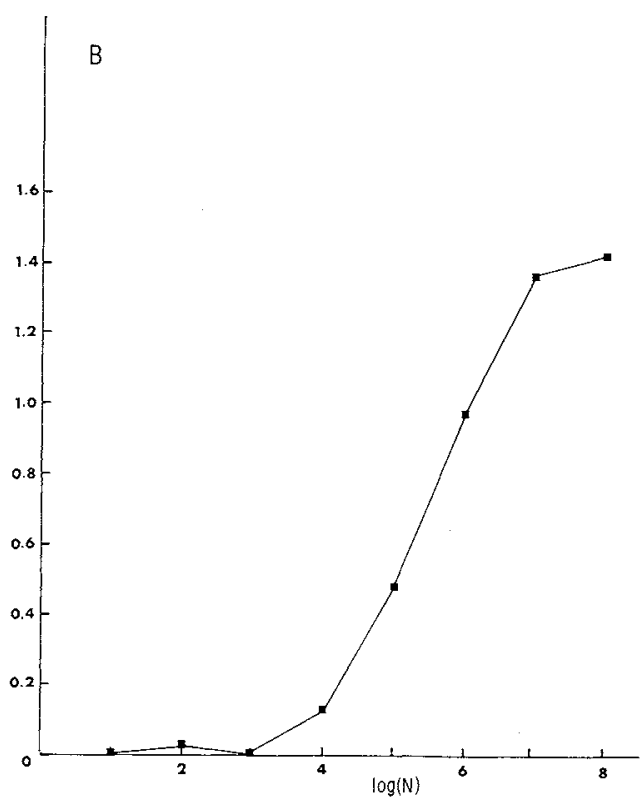

Fig. 5. Correspondence between ELISA Absorbance Values and the Number of Native C. intermedia Suspended in Oragne Juice (A) or PBS (B). 

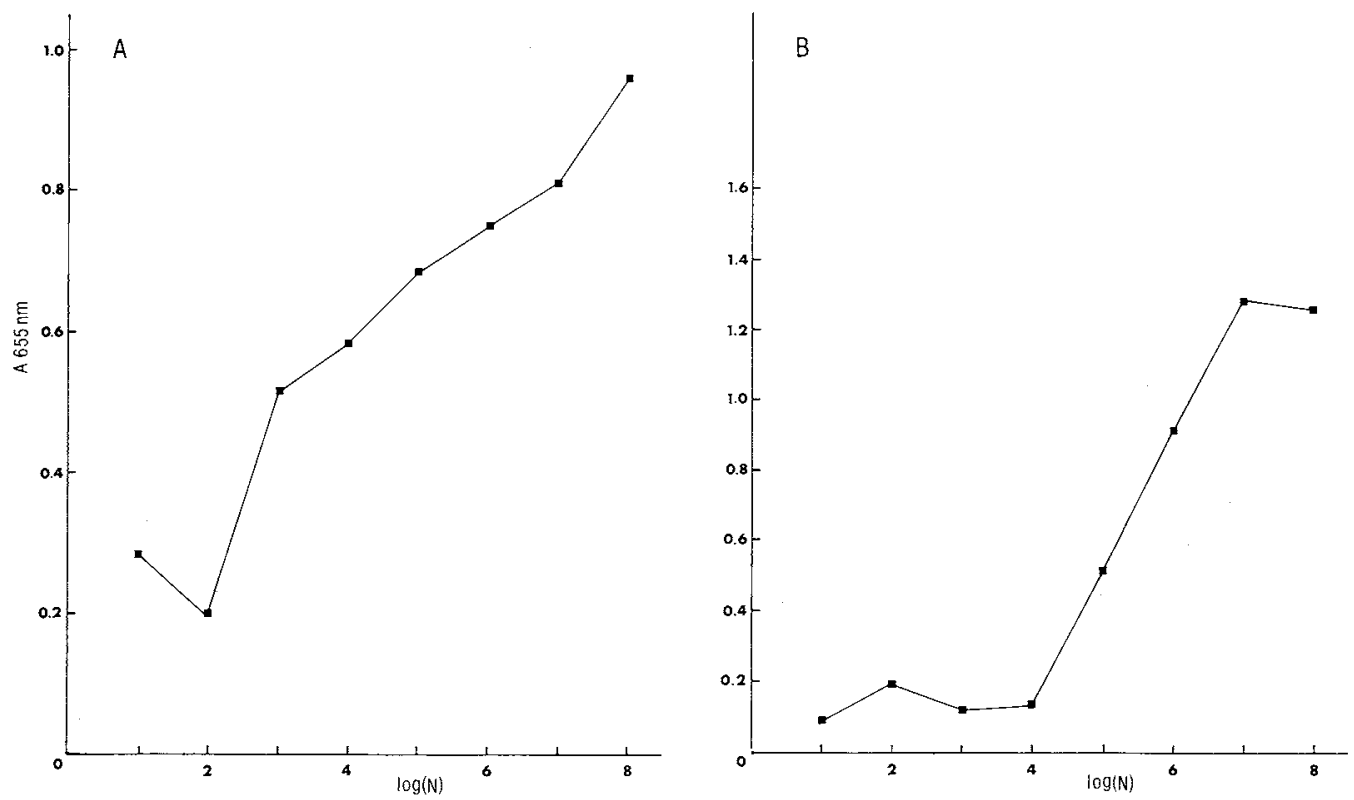

Fig. 6. Correspondence between ELISA Absorbance Values and the Number of Native C. parapsilosis Suspended in Orange Juice (A) or PBS (B).

thought that the reactive antigens of antiserum against $C$. lambica might not be exposed to the outside, or that they might be located in a position difficult for the antibodies to react with under native conditions. The immunodiffusion test showed that the antiserum against C. lambica was of lower titer than that of antisera against the other Candida species (data not shown). It is possible that the cross-reactivities between the antiserum against $C$. lambica and the three species of Candida other than $C$. lambica might not appear in the indirect immunofluorescent method because of the lower titer of the antiserum against $C$. lambica. The results of cells treated with glycosidase, lipase, or Pronase by immunoblotting test suggested that the antigenicity recognized by the antiserum against $C$. intermedia or $C$. parapsilosis consists of protein moieties (Fig. 4). This is corroborated by the results of immunofluorescent assay.

(3) Detection of yeast in orange juice by ELISA

The aim of our investigation was to clarify whether ELISA was applicable for the detection of yeast in orange juice. The antiserum against $C$. intermedia reacted with ten to $1 \times$ $10^{8}$ native $C$. intermedia in PBS by ELISA (Fig. 5B). The same procedure was carried out in C. parapsilosis (Fig. 6B). Both indicated positive relationships between ELISA absorbances and yeast concentrations. ELISA was capable of detecting yeast of more than $10^{3}$. Next, native yeast suspended in orange juice was used as samples for ELISA. The antiserum against $C$. intermedia reacted with native $C$. intermedia in orange juice. The result was similar to that in PBS, although a little decrease in optical density was observed (Fig. 5A). However, a high background was observed in C. parapsilosis (Fig. 6A), which might be due to the cross-reactivity of mingled substances in orange juice with the antiserum against $C$. parapsilosis. In both $C$. intermedia or $C$. parapsilosis in orange juice, yeast of more than $10^{3}$ was able to be detected by ELISA. This degree of sensitivity of ELISA corresponds to that of ATP measurement. ${ }^{12)}$ Graumlich $^{13)}$ reported the application of bioluminescent ATP assay for the detection of microorganisms in orange juice. For the application of this ATP assay, the pH of orange juice must be 
changed by the addition of $0.1 \mathrm{M}$ Tris- $\mathrm{HCl}$ buffer ( $\mathrm{pH} \mathrm{8.0)}$ ) and the microorganisms in orange juice must be ruptured to release the ATP in their cells. The disadvantages of this method are that the substances in orange juice might interfere with the measurement of ATP and that the cost of the ATP assay is high, because of the usage of a valuable enzyme, luciferase. By contrast, ELISA is simple, of low cost, and capable of detecting native microorganisms.

Acknowledgment. We wish to thank Professor S. Goto for his encouragement during this work. This work was supported in part by a grant from Bio-oriented Technology Research Advancement Institution.

\section{References}

I) C. S. Gutteridge and M. L. Arnott, in "Rapid Methods in Food Microbiology," ed. by M. R. Adams and C. F. A. Hope, Elsevier, Amsterdam,
1989, pp. 297-319.

2) H. H. Lin and M. A. Cousin, J. Food Sci. 52, 1089 (1987).

3) M. Yoshida and Y. Iizuka, Cell Struct. Funct., 14, 625 (1989).

4) U. K. Laemmli, Nature, 227, 680 (1970).

5) H. Towbin, T. Staehelin and J. Gordon, Proc. Natl. Acad. Sci. U.S.A., 76, 4350 (1979).

6) M. Kobatake, H. Kurata and K. Komagata, Shokuhin Eiseigaku Zasshi, 19, 417 (1978).

7) T. Tsuchiya, Y. Fukazawa, M. Taguchi, T. Nakase and T. Shinoda, Mycopathol. Mycol. Appl., 53, 77 (1974).

8) M. Yoshida, J. Biochem., 101, 1233 (1987).

9) A. M. S. Marr, A. S. R. Donald, W. M. Watkins and W. T. J. Morgan, Nature, 215, 1345 (1967).

10) C. E. Ballow, P. N. Lipke and W. C. Raschke, J. Bacteriol., 117, 461 (1974).

11) D. J. Manners, A. J. Masson and J. C. Patterson, Biochem. J., 135, 19 (1973).

12) C. J. Stannard, in "Rapid Methods in Food Microbiology" ed. by M. R. Adams and C. F. A. Hope, Elsevier, Amsterdam, 1989, pp. 1-19.

13) T. R. Graumlich, J. Food Sci., 50, 116 (1985). 